\section{CONCLUSION}

Percutaneous absorption of testosterone from the ventral forearm in newborn rhesus monkeys was determined as a measure of skin barrier function. Skin absorption at a concentration of 4 and $40 \mu \mathrm{g} / \mathrm{cm}^{2}$ were, respectively, $22.5 \pm 2.2 \%$ (SD) and $6.8 \pm 2.1 \%$ of the applied dose, values which were not significantly different $(P>0.05)$ from those of adult rhesus and which were similar to man. If the absorption is expressed as micrograms absorbed systemically, then the amounts are 0.9 and 2.7 $\mu \mathrm{g} / \mathrm{cm}^{2}$ area of skin, a 3-fold increase in systemic absorption per 10 -fold increase in topical dose. Occlusion of a dose of $40 \mu \mathrm{g} /$ $\mathrm{cm}^{2}$ enhanced absorption to $14.7 \%$.

The ratio of surface area (square centimeters) to body weight (kilograms) in the newborn is 3 times that in the adult. Therefore, given equal application area of skin per newborn and adult, the systemic availability in the newborn also becomes 3 -fold when based on kilograms of body weight. With a different ratio of skin surface to body weight, the therapeutic ratio probably is lower in the newborn than in the adult when the compound is applied topically. This difference between newborn and adult in systemic availability after topical application may help explain some of the toxicity reported in newborns.

\section{REFERENCES AND NOTES}

1. Armstrong, R. W., Eichner, E. R., Klein, D. E., Barthel, W. F., Bennett, J V., Jonsson, V., Bruce, H., and Loveless, L. E.: Pentachlorophenol poisoning in a nursery for newborn infants. II. Epidemiologic and toxicologic studies. J. Pediat., 75: 317 (1969)
2. Brown, B. W.: Fatal phenol poisoning from improperly laundered diapers. Amer. J. Publ. Health, 60: 901 (1970).

3. Feinblatt, B. I., Aceto, T., Jr., Beckhorn, G., and Bruck, E.: Percutaneous absorption of hydrocortisone in children. Amer. J. Dis. Child., 112: 218 (1966).

4. Feldmann, R. J., and Maibach, H. I.: Percutaneous penetration of steroids in man. J. Invest. Dermatol., 52: 89 (1969).

5. Feldman, R. J., and Maibach, H. I.: Absorption of some organic compounds through the skin in man. J. Invest. Dermatol., 54: 399 (1970).

6. Greaves, S. J., Ferry, D. G., McQueen, E. G., Malcolm, D. S., and Buckfield, P. M.: Serial hexachlorophene blood levels in the premature infant. N. Zealand Med. J., 81: 334 (1975).

7. Lundell, E., and Nordman, R.: A case of infantile poisoning by topical application of Castellani's solution. Ann. Res., 5: 404 (1973).

8. Maibach, H. I.: Ten steps to percutaneous penetration. In: F. Marzulli and H. Maibach: Advances in Toxicology (Hemisphere Publishing Corp., Washington, D.C., in preparation).

9. Marzulli, F. N., and Maibach, H. I.: Relevance of animal models: The hexachlorophene story. In: H. Maibach: Animal Models in Dermatology, pp. 156-167 (Churchill-Livingstone, New York, 1975).

10. Nachman, R. L., and Esterly, N. B.: Increased skin permeability in preterm infants. J. Pediat. 79: 628 (1971).

11. United States Department of Health, Education and Welfare: Radiological Health Handbook, 215 (U. S. Government Printing Office, Washington, D C., 1970).

12. Wester, R. C., and Maibach, H. I.: Percutaneous absorption in the rhesus monkey and man. Toxicol. Appl. Pharmacol., 32: 394 (1975).

13. Wester, R. C., and Maibach, H. I.: Relationships of topical dose and percutaneous absorption in rhesus monkey and man. J. Invest. Dermatol., 67: 518 (1976).

14. We wish to thank Mary Dal Corobbo and June Pautsch for their efforts and dedication in the care of the newborn rhesus monkeys.

15. Requests for reprints should be addressed to: R. C. Wester, Ph.D., Department of Drug Metabolism, Searle Laboratories, Box 5110, Chicago, III. 60680 (USA).

16. Received for publication June $21,1976$.

17. Accepted for publication October 20,1976
Calcium

calcium homeostasis

cord, sera

25-hydroxy-vitamin D magnesium parathyroid hormone serum calcitonin

\title{
Serial Measurements of Serum Calcium, Magnesium, Parathyroid Hormone, Calcitonin, and 25-Hydroxy-Vitamin $D$ in Premature and Term Infants during the First Week of Life
}

\author{
LAURA S. HILLMAN, ${ }^{(50)}$ SOMKIETR ROJANASATHIT, EDUARDO SLATOPOLSKY, AND \\ JOHN G. HADDAD
}

From the Departments of Pediatrics and Medicine, Washington University School of Medicine, and the Division of Neonatology, St. Louis Children's Hospital, Renal Division of Barnes Hospital, and Division of Metabolism, Jewish Hospital of St. Louis, St. Louis, Missouri, USA

\section{Summary}

The mean \pm SEM of the cord, 48-hr, and 7-day values for serum calcium, magnesium, human calcitonin (HCT), parathyroid hormone (PTH), and 25-hydroxy-vitamin D (25OHD) for premature and term infants can be seen in Table 1. Mean cord calcium concentrations were similar for term and premature infants. Serum calcium concentrations fell in both term and premature infants at $48 \mathrm{hr}$, but decreased more in the premature infants (from $10.23 \pm 0.30$ to $8.74 \pm 0.19 \mathrm{mg} / \mathrm{dl}$ ) than in the term infants (from $10.5 \pm 0.26$ to $9.6 \pm 0.23 \mathrm{mg} / \mathrm{dl}$ ). Serum calcium values increased from $48 \mathrm{hr}$ to 7 days in both groups, and there was no significant difference between term and premature infants' serum calcium concentrations $(10.6 \pm$ 0.28 and $10.12 \pm 0.3 \mathrm{mg} / \mathrm{dl}$, respectively) at that time. There was no significant difference between term and premature cord serum magnesium concentrations. Serum magnesium concentrations increased similarly by $48 \mathrm{hr}$ in both groups and remained at these concentrations at 7 days of life. Serum HCT concentrations were elevated above normal adult levels $(71.9 \pm 6.6 \mathrm{pg} / \mathrm{ml}$, 
$81 \%<100 \mathrm{pg} / \mathrm{ml}, n=63$ ) in both premature and term cord sera, but premature cord concentrations $(146 \pm 24 \mathrm{pg} / \mathrm{ml})$ were significantly higher than term cord concentration $(91 \pm 21 \mathrm{pg} /$ $\mathrm{ml}$ ). Both term and premature infants displayed a 2-3-fold increase in serum HCT by $48 \mathrm{hr}$ and a partial fall by 7 days to concentrations still above those seen in cord sera (Fig. 1). Nine of 10 premature and 9 of 10 term infants had undetectable PTH concentrations in cord sera. In two premature infants, PTH serum concentration remained undetectable at $48 \mathrm{hr}$. However, the majority of both premature and term infants had elevated levels of PTH at $48 \mathrm{hr}$. The mean PTH concentrations were lower but still elevated at 7 days with the suggestion of higher concentrations in premature infants (Fig. 2). There were no significant differences in serum 25-OHD concentrations between term and premature sera at birth or at 7 days.

There was a weakly positive correlation between 25-OHD and cord calcium $(r=0.45, P<0.05)$, and a negative correlation between cord calcium and 48-hr PTH $(r=-0.53, P<0.01)$. Calcium and magnesium were significantly positively correlated in 48-hr $(r=0.83)$ and 7-day $(r=0.84)$ sera in premature infants but not in term infants. Cord 25-OHD and cord HCT levels were significantly positively correlated $(r=0.80, P<$ 0.01 ) in the term infants but not the premature infants.

\section{Speculation}

HCT may play a significant role in perinatal mineralization of bone and the high levels seen in premature infants may contribute to early neonatal hypocalcemia. Lack of PTH compensatory response in a subgroup of premature infants and magnesium deficiency in selected premature infants may further compromise calcium homeostasis. Evidence for a primary role of 25-0HD deficiency in early neonatal hypocalcemia was not found. The role of vitamin $D$ in placental calcium transport and the interaction of vitamin D and HCT in perinatal bone turnover require further study.

The majority of premature infants experience a brief period of decreased serum calcium at $24-48 \mathrm{hr}$ of life. When the decrease is significant, the diagnosis of early neonatal hypocalcemia is made (43). The pathogenesis of this fall in serum calcium has not been clearly defined; however, inadequate PTH secretion $(7,39)$ and increased serum HCT concentrations $(8,11)$ have been implicated. Magnesium deficiency may also cause decreased PTH secretion and/or end organ response $(1,4)$. PTH increases gastrointestinal calcium absorption by increasing conversion of $25-\mathrm{OHD}$ to 1,25 -dihydroxyvitamin $\mathrm{D}\left(1,25-(\mathrm{OH})_{2} \mathrm{D}\right)$ $(10,12)$ which increases calcium transport across the gastrointestinal mucosa (26). The efficacy of PTH in the resorption of bone is facilitated by adequate vitamin $D$ (26). Conceivably, effective vitamin $\mathrm{D}$ deficiency could be a factor con- tributing to significant decreases in serum calcium in the early neonatal period. Rosen et al. (34) found low serum 25-OHD concentrations in some premature infants with early neonatal hypocalcemia and suggested such an etiologic relationship. Cord serum 25-OHD concentrations are directly related to maternal serum 25-OHD concentrations (16).-During periods of decreased ultraviolet exposure, decreased vitamin $\mathrm{D}$ intake and sampling prior to term can result in lower maternal serum 25-OHD concentrations (18). Furthermore, premature infants (17) and young experimental animals (24) do not sustain or increase their serum concentrations of $25-\mathrm{OHD}$ in the immediate postnatal period.

We have therefore analyzed serial sera (cord, 48-hr and 7day) from premature and term infants for calcium, magnesium, HCT, PTH, and 25-OHD in order to gain a more comprehensive view of neonatal calcium homeostasis.

\section{METHODS}

\section{PATIENTS}

Eleven premature and 10 term infants were studied during their initial hospitalization in St. Louis in February 1976. All sequentially born, healthy premature infants were studied. The premature infants weighed $1500-2000 \mathrm{~g}$ and were born after $31-$ 36 weeks of gestation. They were healthy prematures who were able to begin oral feedings of a standard formula within the first $24 \mathrm{hr}$ of life, and only one required limited oxygen therapy. Except for ampicillin and kanamycin, they received no additional drugs or vitamin supplements. The term infants were randomly selected infants delivered by cesarian section for various reasons but had no neonatal problems requiring more than the routine observation for $6 \mathrm{hr}$. Informed consent was obtained from parents of all infants.

\section{BLOOD SAMPLES}

Cord blood was centrifuged and the serum frozen within $3 \mathrm{hr}$; $2.5 \mathrm{ml}$ blood were obtained by heel stick at $48 \mathrm{hr}$ and at 7 days of age, and the blood was allowed to clot at room temperature. It was then centrifuged and the serum frozen. All sera were stored frozen until samples from all 21 babies had been obtained.

\section{ASSAYS}

25-OHD was measured by the competitive protein binding radioassay of Haddad and Chyu (15). Calcium and magnesium were measured on a flame atomic absorption spectrometer as described previously $(13,29)$. PTH was measured by a radioimmunoassay, which uses a rooster antiserum to bovine PTH that recognizes intact hormone $(1-84)$ and carboxyterminal fragments (21). HCT was measured by a sensitive HCT radioimmunoassay which uses a guinea pig antiserum that recognized intact

Table 1. Serial calcium, magnesium, calcitonin, parathyroid hormone (PTH), and 25-hydroxy vitamin D (25-OHD) in premature and term infants

\begin{tabular}{|c|c|c|c|c|c|c|c|c|c|c|}
\hline & Infants & $\begin{array}{l}\text { Cord blood, } \\
\text { mean } \pm \mathrm{SE}\end{array}$ & Range & $n$ & $\begin{array}{l}48 \pm 2 \mathrm{hr} \\
\text { mean } \pm \mathrm{SE}\end{array}$ & Range & $n$ & $\begin{array}{c}7 \text { days, mean } \\
\pm \mathrm{SE} \\
\end{array}$ & Range & $n$ \\
\hline $\mathrm{Ca}, \mathrm{mg} / \mathrm{dl} \quad(9.0-$ & Term & $10.5 \pm 0.26$ & $9.6-12.6$ & 10 & $9.6 \pm 0.23^{1}$ & $8.8-10.3$ & 9 & $10.60 \pm 0.28$ & $9.0-11.8$ & 10 \\
\hline $11.0 \mathrm{nl})$ & Premature & $10.23 \pm 0.30$ & $8.8-12.5$ & 11 & $8.74 \pm 0.19$ & $7.6-9.6$ & 10 & $10.12 \pm 0.30$ & $8.5-11.6$ & 11 \\
\hline $\mathrm{Mg}, \mathrm{mEq} / \mathrm{liter}$ & Term & $1.56 \pm 0.04$ & $1.43-1.78$ & 9 & $1.88 \pm 0.06$ & $1.55-2.16$ & 8 & $1.80 \pm 0.06$ & $1.52-2.09$ & 9 \\
\hline$(1.4-2.3 \mathrm{nl})$ & Premature & $1.62 \pm 0.13$ & $1.24-2.54$ & 9 & $1.88 \pm 0.08$ & $1.54-2.20$ & 8 & $1.97 \pm 0.08$ & $1.42-2.26$ & 9 \\
\hline $\begin{array}{c}\text { Calcitonin, } \mathrm{pg} / \mathrm{ml} \\
(71 \pm 6 \mathrm{pg} / \mathrm{ml})\end{array}$ & $\begin{array}{l}\text { Term } \\
\text { Premature }\end{array}$ & $\begin{aligned} 91 & \pm 21^{2} \\
146 & \pm 24\end{aligned}$ & $\begin{array}{l}30-240 \\
30-265\end{array}$ & $\begin{array}{l}10 \\
11\end{array}$ & $\begin{array}{l}295 \pm 59 \\
378 \pm 65\end{array}$ & $\begin{array}{r}91-580 \\
108-670\end{array}$ & $\begin{array}{r}9 \\
10\end{array}$ & $\begin{array}{l}151 \pm 22^{3} \\
225 \pm 40\end{array}$ & $\begin{array}{l}77-293 \\
79-570\end{array}$ & $\begin{array}{l}10 \\
11\end{array}$ \\
\hline $\begin{array}{l}\mathrm{PTH}, \mu \mathrm{l} \mathrm{Eq} / \mathrm{ml}(2- \\
10 \mathrm{nl})\end{array}$ & $\begin{array}{l}\text { Term } \\
\text { Premature }\end{array}$ & $\begin{array}{l}9 \text { of } 10 \\
9 \text { of } 10\end{array}$ & 9 of 10 undetectable & & $\begin{array}{l}16.2 \pm 2.1 \\
19.7 \pm 4.9\end{array}$ & $\begin{array}{l}9-25 \\
7-50\end{array}$ & $\begin{array}{r}7 \\
9\end{array}$ & $\begin{array}{l}11.6 \pm 1.8^{3} \\
15.5 \pm 1.9\end{array}$ & $\begin{array}{r}<7->20 \\
8->20\end{array}$ & $\begin{array}{r}8 \\
10\end{array}$ \\
\hline $\begin{array}{l}\text { 25-OHD, } \mathrm{ng} / \mathrm{ml} \\
(10-60 \mathrm{nl})\end{array}$ & $\begin{array}{l}\text { Term } \\
\text { Premature }\end{array}$ & $\begin{array}{r}14.2 \pm 2.5 \\
11.27 \pm 1.4\end{array}$ & $\begin{array}{l}4-26 \\
6-20\end{array}$ & $\begin{array}{l}10 \\
11\end{array}$ & & & & $\begin{array}{l}11.4 \pm 0.8 \\
12.3 \pm 1.5\end{array}$ & $\begin{array}{l}9-16 \\
7-19\end{array}$ & $\begin{array}{r}9^{4} \\
10^{4}\end{array}$ \\
\hline
\end{tabular}

${ }^{1} P<0.005$ that term and premature values are different by chance.

${ }^{2} P<0.05$ that term and premature values are different by chance.

${ }^{3} 0.05<P<0.1$ that term and premature values are different by chance.

4 Separate assay from cord 25-OHD values. 
HCT and its carboxyterminal fragments (32). Because of the limited volume of sera, 25-OHD concentrations were not performed on 48-hr samples. Cord and 7-day 25-OHD samples were assayed in two separate assays. All of the sequential PTH and $\mathrm{HCT}$ measurements were made in single assays to avoid interassay variation. All serum calcium and magnesium determinations were analyzed on the same day.

\section{RESULTS}

The mean \pm SEM of the cord, 48-hr, and 7-day values for serum calcium, magensium, HCT, PTH, and 25-OHD for premature and term infants can be seen in Table 1 .

\section{CALCIUM}

Mean cord calcium concentrations were similar for term and premature infants at $48 \mathrm{hr}$, but decreased more in the prematures (from $10.23 \pm 0.30$ to $8.74 \pm 0.19 \mathrm{mg} / \mathrm{dl}$ ) than in the term infants (from $10.5 \pm 0.26$ to $9.6 \pm 0.23 \mathrm{mg} / \mathrm{dl}$ ). Serum calcium values increased from $48 \mathrm{hr}$ to 7 days, at which time there was no significant difference between term and premature infants' serum calcium concentrations $(10.6 \pm 0.28$ and $10.12 \pm 0.3 \mathrm{mg} /$ $\mathrm{dl}$, respectively).

\section{MAGNESIUM}

There was no significant difference between term and premature cord serum magnesium concentrations. Serum magnesium concentrations increased similarly by $48 \mathrm{hr}$ in both groups and remained at these concentrations at 7 days of life.

\section{HCT}

HCT serum concentrations were elevated above normal adult levels $(71.9 \pm 6.6 \mathrm{pg} / \mathrm{ml}, 81 \%<100 \mathrm{pg} / \mathrm{ml}, n=63)$, in both premature and term cord sera, but premature cord concentrations $(146 \pm 24 \mathrm{pg} / \mathrm{ml})$ were significantly higher than term cord concentration $(91 \pm 21 \mathrm{pg} / \mathrm{ml})$. Both term and premature infants displayed a 2-3-fold increase in serum HCT by $48 \mathrm{hr}$ and a partial fall by 7 days to concentrations which were still above those seen in cord sera (Fig. 1).

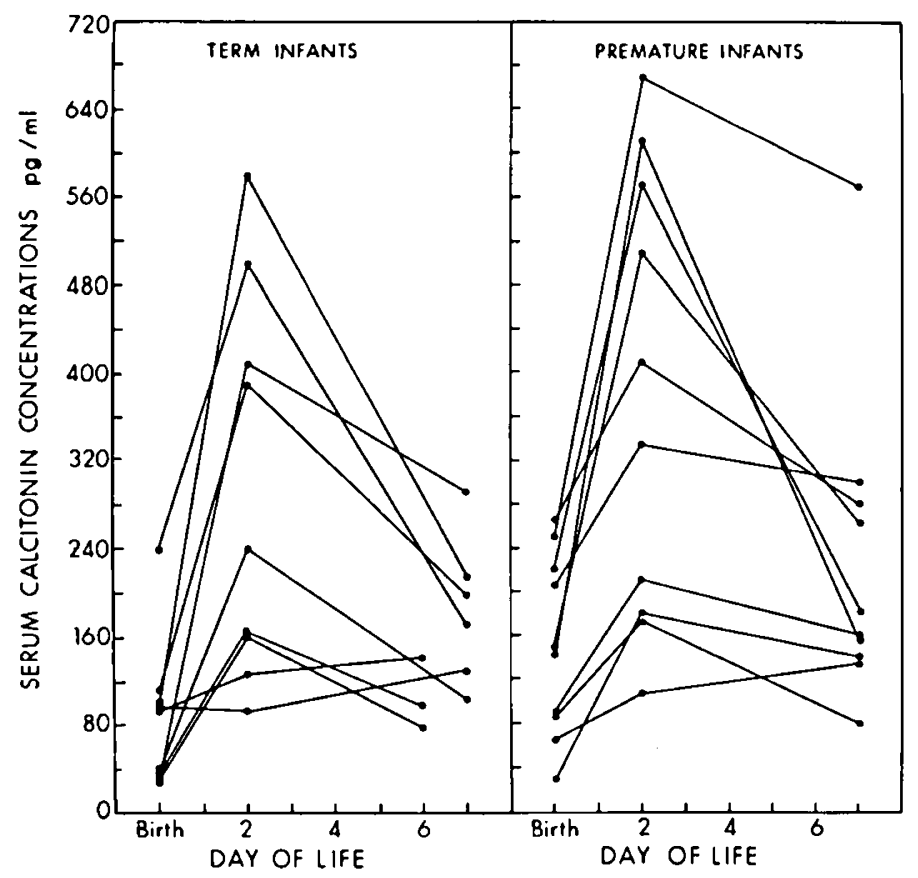

Fig. 1. Cord, 48-hr, and 7-day serum calcitonin in term infants (left) and premature infants (right). Adult mean \pm SEM, $71.9 \pm 6.6 \mathrm{pg} / \mathrm{ml}$.

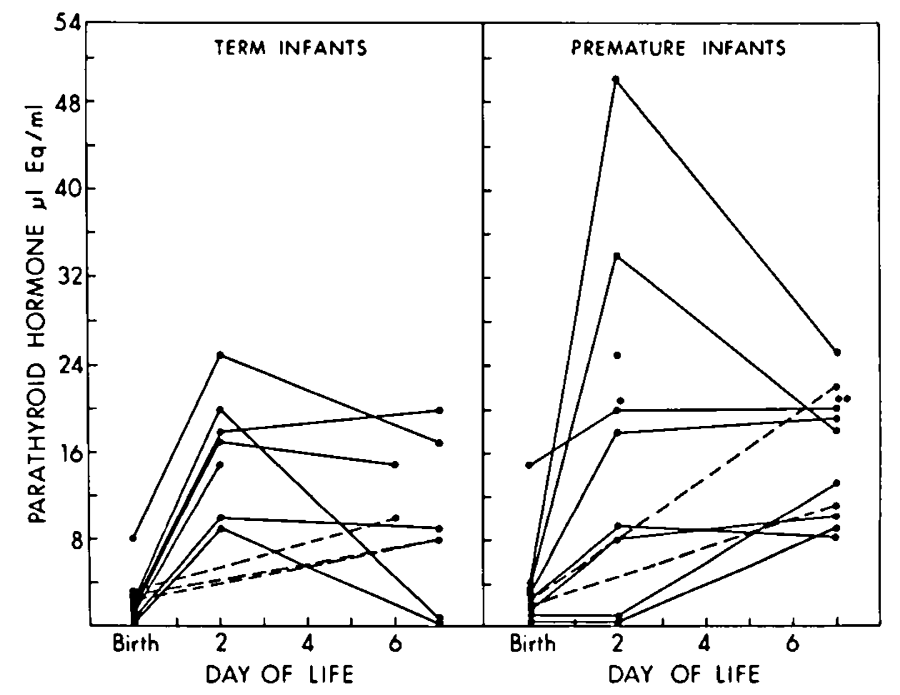

Fig. 2. Cord, 48-hr, and 7-day serum parathyroid hormone in term infants $(l e f t)$ and premature infants $(r i g h t) .^{*}:>20{ }^{* *}:>>20$. Normal parathyroid hormone range: $2-10 \mu \mathrm{l} \mathrm{Eq} / \mathrm{ml}$.

PTH

Nine of 10 premature and 9 of 10 term infants had undetectable PTH concentrations in cord sera. In two premature infants, serum PTH concentration remained undetectable at $48 \mathrm{hr}$. However, the majority of both premature and term infants had elevated levels of PTH at $48 \mathrm{hr}$. The mean PTH concentrations were lower but still elevated at 7 days with slightly higher concentrations in premature infants (Fig. 2).

\section{5-OHD}

There were no significant differences in serum 25-OHD concentrations between term and premature sera at birth or at 7 days.

\section{CORRELATIONS}

There was a weak positive correlation between 25-OHD and cord calcium $(r=0.45, P<0.05)$, and a negative correlation between cord calcium and 48-hr PTH $(r=-0.53, P<0.01)$. Calcium and magnesium were significantly positively correlated in 48-hr $(r=0.83)$ and 7-day $(r=0.84)$ sera in premature infants but not in term infants. Cord 25-OHD and cord HCT concentrations were significantly positively correlated $(r=$ $0.80), P<0.01)$ in the term infants but not the premature infants. No significant correlations were found among the other parameters analyzed, including HCT and PTH ratios and cord 48-hr calcium differences. Individual data from the four prematures with the lowest 48 -hr serum calcium concentrations $(<8.5$ $\mathrm{mg} / \mathrm{dl}$ ) can be seen in Table 2 .

\section{DISCUSSION}

This study was designed to examine serially some of the factors important to early neonatal extracellular calcium homeostasis, since such a study does not exist in the literature. Although all of these factors are relevant to early neonatal hypocalcemia, the study was done in a prospective fashion so that $48-\mathrm{hr}$ serum calcium values were unknown. The premature population studied was not the population with the highest incidence of early hypocalcemia; i.e., sick infants, NPO, $<32$ weeks of gestation. Nevertheless, there was a significant difference between the mean $48-\mathrm{hr}$ calcium value in premature infants $(8.7 \pm 0.19$ $\mathrm{mg} / \mathrm{dl})$ and term infants $(9.6 \pm 0.23 \mathrm{mg} / \mathrm{dl})(P<0.005)$. The premature infants had significantly higher cord HCT concentrations in spite of the similar calcium concentrations in term and 
Table 2. Premature infants with $48-h$ calcium $<8.5^{1}$

\begin{tabular}{|c|c|c|c|c|c|c|c|}
\hline Infant & $\begin{array}{c}\text { 48-hr Ca, mg/ } \\
\text { dl }\end{array}$ & $\begin{array}{l}48-\mathrm{hr} \text { calci- } \\
\text { tonin, } \mathrm{pg} / \mathrm{ml}\end{array}$ & $\begin{array}{c}\text { 48-hr PTH, } \mu \mathrm{l} \\
\mathrm{Eq} / \mathrm{ml}\end{array}$ & $\begin{array}{l}\text { 48-hr } \mathrm{Mg}, \mathrm{mEq} / \\
\text { liter }\end{array}$ & $\begin{array}{c}\text { Cord } 25-\text { OHD, } \\
\mathrm{ng} / \mathrm{ml}\end{array}$ & Cord $\mathrm{Ca}, \mathrm{mg} / \mathrm{dl}$ & $\begin{array}{c}\text { Cord } \mathrm{Mg}, \mathrm{mEq} / \\
\text { liter }\end{array}$ \\
\hline$W$ & 8.3 & 410 & 9 & 2.15 & 8 & 10.3 & \\
\hline$M$ & 7.6 & 179 & 8 & 1.54 & 20 & 10.2 & 1.3 \\
\hline$R$ & 8.4 & 610 & $\begin{array}{l}\text { Undetectable } \\
\qquad(<7)\end{array}$ & 1.83 & 18 & 12.5 & 1.8 \\
\hline$A$ & 8.3 & 570 & 50 & 1.86 & 6 & 9.3 & 1.24 \\
\hline $\begin{array}{l}\text { Mean } \pm \text { SE } \\
\text { (premature } \\
\text { infants) }\end{array}$ & $8.74 \pm 1.9$ & $378 \pm 65$ & $19.7 \pm 4.9$ & $1.88 \pm 0.08$ & $11.27 \pm 1.4$ & $10.23 \pm 0.30$ & $1.62 \pm 0.13$ \\
\hline
\end{tabular}

'PTH: parathyroid hormone; 25-OHD: 25-hydroxy-vitamin D.

premature cord sera. Cord HCT concentrations were not correlated with cord total calcium in this study, and there was also no correlation with cord-ionized calcium in 10 samples previously studied by us (32). All but one term infant showed a further marked increase in HCT by $48 \mathrm{hr}$. Others have shown that the peak in serum HCT is at about $24 \mathrm{hr}(8,11)$. Serum glucagon and epinephrine, which are markedly increased shortly after birth, may stimulate HCT release (33) and be in part responsible for the HCT increase seen in all of the infants studied. In a very large series, Dirksen and Anast (11) have shown increased serum HCT concentrations in infants who have significant hypocalcemia during the first $48 \mathrm{hr}$ of life. Serum HCT remained significantly elevated above cord concentrations in both groups at 7 days and HCT concentrations in the premature infants remained slightly higher $(P<0.1)$ than those of the term infants. HCT may play a significant role in promoting in utero and postnatal bone mineralization, and possibly promoting placental transport of calcium. HCT blocks bone resorption, especially in young animals with rapid bone turnover. In rats, young age and a diet high in phosphate predispose to a greater hypocalcemia response to HCT injection (35). However, HCT has had limited usefulness in treating hypercalcemia of adults, and adult patients with medullary cancer of the thyroid and very high serum HCT do not have hypocalcemia or increased serum PTH (9). Increased HCT concentrations also are associated with decreased receptor sites for HCT in bone (46). Although there is not much precedent for HCT causing hypocalcemia in adult humans, this possibility exists in the human newborn infant.

There were no significant differences between the serum PTH concentrations of term and premature infants. Eighteen of 20 cord serum PTH concentrations were undetectable $(<7 \mu \mathrm{lEq} /$ $\mathrm{ml}$ ), and it has been postulated that this represents a functional suppression secondary to the high fetal serum ionized calcium concentrations, which are maintained by active transport of calcium across the placenta (40). The one infant with an elevated cord PTH concentration $(15 \mu \mathrm{l} \mathrm{Eq} / \mathrm{ml})$ had the lowest cord calcium $(8.8 \mathrm{mg} / \mathrm{dl})$. By $48 \mathrm{hr}$, most of the infants had elevated PTH levels which exhibited a significantly negative correlation with cord calcium $(r=0.53, P<0.01)$. Tsang et al. (40) have shown a similar negative correlation in infants of diabetic mothers between cord ionized calcium and $\mathrm{PTH}$ serum concentrations using an $N$-terminal radioimmunoassay; however, they did not show this correlation in normal infants. Whereas the term infants presented a homogeneous intermediate PTH response, the premature infants fell into two groups, six infants with high PTH levels at $48 \mathrm{hr}$ and at 7 days, and five infants with undetectable or normal levels at $48 \mathrm{hr}$ and at 7 days (Fig. 2). Although a correlation between serum PTH concentration and 48-hr serum calcium concentrations could not be made, three of the four infants with the lowest 48-hr serum calcium values (calcium < $8.5 \mathrm{mg} / \mathrm{dl}$ ) were from this group of five infants with the lower PTH responses.

Tsang et al. (39), using an $N$-terminal radioimmunoassay, have found lower PTH levels in the majority of the premature infants they have studied. Also, Tsang et al. (39) showed a decrease in the magnitude of $\mathrm{PTH}$ response to the hypocalcemia of exchange transfusion with decreasing gestation as well as before $52 \mathrm{hr}$ of age compared to after $52 \mathrm{hr}$ of age. David and Anast (7), using the same $C$-terminal antisera used in our assay, have shown elevated PTH serum concentrations in normal and especially "sick," but not hypocalcemic infants. In other studies with a different antisera, David et al. (8) report consistently high levels of PTH in premature infants. The variation in data from different investigators probably results from the use of different antisera and reviews of these differences have been published $(2$, 33). $N$-terminal assays may be best to measure acute secretion, but may underdetect chronic conditions. Carboxyterminal assays diagnose chronic conditions, but may overestimate serum PTH concentrations because of their recognition of inactive, carboxyterminal fragments in the circulation. If renal degradation of PTH fragments is impaired in the premature infant, this could cause a serious overestimation of PTH secretion.

In recent studies of late neonatal hypocalcemia tetany, a high incidence of hypomagnesemia has been preorted $(5,6)$. Tsang and $\mathrm{Oh}(42)$ reported magnesium deficiency in small for gestational age infants and have recently reported transient hypomagnesemia in a high percentage of infants of diabetic mothers (44). The general prevalance of maternal hypomagnesemia is just coming under study (3). In this study, serum magnesium concentrations were similar and followed identical courses in term and appropriate for gestational age (AGA) premature infants as previously seen in a larger series (42). The significant positive correlation between serum magensium and serum calcium at both $48 \mathrm{hr}$ and 7 days seen in premature infants, but not term infants, raises the possibility of a direct relationship between magnesium and calcium homeostasis in AGA prematures.

Questions remain about the ability of PTH target tissues in premature infants to respond to PTH and vitamin D. In term infants, urinary cyclic AMP and urinary phosphate excretion increase in a parallel fashion to PTH increase in the first 3 days of life (23) and exogenous PTH can produce an increase in cyclic urinary AMP and phosphate excretion (23). However, in hypocalcemic premature infants, no cyclic AMP response was seen to exogenous PTH (22). Tsang et al. (41) demonstrated an increased serum calcium in premature infants in response to exogenous PTH; however, the mechanism of that increase is unknown. PTH acts to increase the conversion of 25-OHD to 1,25$(\mathrm{OH})_{2} \mathrm{D}$, the active form of vitamin $\mathrm{D}$, which increases calcium transport in the gastrointestinal tract $(10,25) .1,25-(\mathrm{OH})_{2} \mathrm{D}$ may also be important in the PTH-initiated mobilization of calcium from bone (26). This 1-hydroxylation of 25-OHD occurs in the kidney tubules, and it is not known whether the immature human kidney can carry out this conversion. Since large amounts of sera are necessary to measure $1,25-(\mathrm{OH})_{2} \mathrm{D}$, $1,25-(\mathrm{OH})_{2} \mathrm{D}$ serum concentrations have not been studied in premature infants. Since serum 25-OHD concentrations often fall in premature infants (17), suggesting decreased 25-hydroxylation in the liver (24), a period of decreased 25-OHD 1-hydroxylation by the kidney would not be surprising.

Because maternal serum 25-OHD concentrations determine infant serum $25-O H D$ concentrations, we have previously studied the factors contributing to low maternal serum 25-OHD 
concentration in St. Louis (18). The predominant factor was season at time of sampling. During winter vitamin $D$ intake was weakly correlated with 25 -OHD serum concentrations. The hypocalcemia infants in the study of Rosen et al. (34) were also winterborn and those whose mothers had low vitamin $D$ intakes had low 25-OHD levels, whereas those whose mothers had good vitamin $D$ intakes had normal levels. The population in this study was a mixture of socioeconomic classes with varying prenatal care and vitamin intakes during pregnancy but all born within the month of February. This was predicted to give a significant range of serum 25-OHD concentrations with many low values. This indeed occurred for both the term infants (14.2 $\pm 2.5,4-26$ $\mathrm{ng} / \mathrm{ml})$ and premature infants $(11.27 \pm 1.9,6-20 \mathrm{ng} / \mathrm{ml})$. The data presented provides no support for a role of $25-\mathrm{OHD}$ deficiency in early neonatal hypocalcemia. Although the premature infants studied had significantly lower serum calcium concentrations at $48 \mathrm{hr}$ than the full term infants, their 25-OHD levels were not different from those of the term infants at either birth or at 7 days. Further, there was no correlation between low 25OHD levels and low 48-hr serum calcium concentrations in either the term or premature infants. A correlation between normal serum 25-OHD and calcium has not usually been found $(18,36)$. Gupta et al. (14), however, found a correlation between 25-OHD serum concentrations and serum calcium in a group of D-deficient Asians having a mean serum 25-OHD concentration of $9.9 \mathrm{ng} / \mathrm{ml}$ in April and $14.7 \mathrm{ng} / \mathrm{ml}$ in October and mean calcium concentration of $8.9 \mathrm{mg} / \mathrm{dl}$ in April and 9.25 $\mathrm{mg} / \mathrm{dl}$ in October. We have found very late hypocalcemia $(19$, $20)$ in 11 premature infants with very low 25-OHD levels. Severe osteopenia, often progressing to frank rickets, was seen in these infants. Similarly, in adult Asians in Britain who were chronically vitamin D deficient, hypocalcemia and increased alkaline phosphatase were seen at $25-\mathrm{OHD}$ levels of $2.2 \pm 0.9$ $\mathrm{ng} / \mathrm{ml}$ and rickets at concentrations $<0.8 \mathrm{ng} / \mathrm{ml}(27)$.

In the present series, sampled in winter to give a low range of 25-OHD concentrations, there was a weak correlation $(r=$ $0.45, P<0.05$ ) between cord 25-OHD and cord calcium but not magnesium. Roginsky et al. (31), in a series of 37 cord blood samples, did not find such a correlation. More studies are needed to see whether vitamin D plays any role in placental calcium transport similar to its role in gastrointestinal calcium transport. There was also a positive correlation $(r=0.80, P<$ 0.01 ) between cord 25-OHD and cord HCT in the 10 term infants but no correlation ( $r=-0.54, P$ not significant) in the 11 premature infants. A direct relationship between 25-OHD concentrations and PTH was not suggested by this study.

The incidence of late neonatal hypocalcemia is so low that the lack of correlation between 25-OHD and 7-day calcium in this small series does not rule out a role for 25-OHD deficiency in late neonatal hypocalcemia. The epidemiological data for such an association is quite good $(28,30,45)$, and a larger prospective study is in progress.

\section{CONCLUSION}

Serial determinations of serum calcium, magnesium, calcitonin, PTH, and 25-OHD in a series of premature and term infants indicate lower 48 -hr serum calcium concentrations and higher serum HCT concentrations in premature infants. Hypocalcemia may be further provoked by lack of a PTH compensatory response in a subgroup of premature infants, and magnesium deficiency in selected infants. Evidence for a primary role of 25-OHD deficiency in early neonatal hypocalcemia was not found; however, 25-OHD $1 \alpha$-hydroxylase activity was not appraised.

\section{REFERENCES AND NOTES}

1. Anast, C., Mohns, J., Kaplan, S., and Burns, T.: Evidence for parathyroid failure in magnesium deficiency. Science, 177: 606 (1972).

2. Arnaud, Goldsmith, R., Bordier, P., Sizemore, G., Larsen, J., and Gilkinson, J.: Influence of immunoheterogeneity of circulating parathyroid hormone on results of radioimmunoassays of serum in man. Amer. J. Med., 56: 785 (1974).

3. Caddell, J., Saier, F., and Thomason, C.: Parenteral magnesium load tests in postpartum American women. Amer. J. Clin. Nutr., 28: 1099 (1975)

4. Chase, L., and Slatopolsky, E.: Secretion and metabolic efficacy of parathyroid hormone in patients with severe hypomagnesemia. J. Clin. Endocrinol. Metab., 38: 363 (1974).

5. Chiswick, M.: Association of oedema and hypomagnesaemia with hypocalcemic tetany of the newborn. Brit. Med. J., 3: 15 (1971).

6. Cockburn, F., Brown, J., Bclton, N., and Forfar, J.: Neonatal convulsions associated with primary disturbance of calcium, phosphorus, and magnesium metabolism. Arch. Dis. Childhood, 48: 99 (1973).

7. David, L., and Anast, C.: Calcium metabolism in newborn infants: The interrelationship of parathyroid function and calcium, magnesium and phosphorus metabolism in normal, "sick" and hypocalcemia newborns. J. Clin. Invest., 54: 287 (1974).

8. David, L., Salle, B., Chopard, P., and Grafmeyer, D.: Parathormone (PTH) and calcitonin $(\mathrm{CT})$ in prematures with and without calcium infusion [Abstr.]. Pediat. Res., 10: 407 (1976).

9. Deftos, L.: Radioimmunoassay for calcitonin in medullary thyroid carcinoma. J.A.M.A., 227: 403 (1974)

10. DeLuca, H.: The kidney as an endocrine organ for the production of 1,25 dihydroxy-vitamin $D_{3}$, a calcium-mobilizing hormone. N. Engl. J. Med., 289: 359 (1973).

11. Dirksen, H., and Anast, C.: Interrelationships of serum immunoreactive calcitonin (iCT) and serum calcium in newborn infants [Abstr.]. Pediat. Res., 10: 408 (1976).

12. Fraser, D., and Kodicek, E.: Regulation of 25-hydroxycholecalciferol-1-hydroxylase activity in kidney by parathyroid hormone. Nature New Biol., 241: 163 (1973).

13. Gochman, N., and Givelbar, H.: Automated, simultaneous, microdetermination of calcium and magnesium by atomic absorption. Clin Chem., 16: 229 (1970).

14. Gupta, M., Round, J., and Stamp, T.: Spontaneous cure of vitamin D deficiency in Asians during summer in Britain. Lancet 1: 586 (1974).

15. Haddad, J., and Chyu, K.: Competitive protein-binding radioassay for 25 hydroxycholecalciferol. J. Clin Endocrinol., 33: 992 (1971).

16. Hillman, L., and Haddad, J.: Perinatal vitamin D metabolism. I. 25-Hydroxyvitamin $\mathrm{D}$ in maternal and cord blood. J. Pediat., 84: 742 (1974).

17. Hillman, L., and Haddad, J.: Perinatal vitamin D metabolism. II. Serial 25hydroxy-vitamin $\mathrm{D}$ concentrations in sera of term and premature infants. J. Pediat., 86: 928 (1975).

18. Hillman, L., and Haddad, J.: Perinatal vitamin D metabolism. III. Factors influencing late gestational human serum 25-hydroxyvitamin D. Amer. J. Obstet. Gynecol., 125: 196 (1976).

19. Hoff, N., Tyrala, E., Haddad, J., and Hillman, L.: 25-Hydroxyvitamin D deficiency in osteopenia of the extreme premature [Abstr.]. Pediat. Res., 10: 410 (1976).

20. Hoff, N., Tyrala, E., Haddad, J., and Hillman, L.: Perinatal vitamin D metabolism. IV. The role of 25 -hydroxyvitamin D deficiency in osteopenia and rickets in the extreme premature. (In preparation.)

21. Hruska, K., Kopelman, R., Rutherford, W., Klahr, S., and Slatopolsky, E. Metabolism of immunoreactive parathyroid hormone in the dog. J. Clin. Invest., 56: 39 (1975).

22. Linarelli, L., Bobik, C., and Bobik J.: Renal cyclic AMP response to parathyroid hormone in premature hypocalcemia infants. J. Pediatr., 84: 914A (1974).

23. Linarelli, L., Bobik, J., and Bobik, C.: Newborn urinary cyclic AMP and developmental renal repsonsiveness to parathyroid hormone. Pediatrics, 50 : 15 (1972).

24. Mendelsohn, M., and Haddad, J.: Postnatal fall and rise of circulating 25hydroxy-vitamin D in the rat. J. Lab. Clin. Med., 86: 32 (1975).

25. Olson, E., Jr., DeLuca, H., and Potts, J., Jr.: The effect of calcitonin and parathyroid hormone on calcium transport of isolated intestine. In: R. V Talmage and R. L. Munson: Calcium, Parathyroid Hormone and the Calcitonins, p. 240 (Excerpta Medica, Amsterdam, 1972).

26. Potts, J., Jr., and Deftos, L.: Parathyroid hormone, calcitonin, vitamin D, bone and bone mineral metabolism. In: P. K. Bondy and L. E. Rosenberg: Duncan's Diseases of Metabolism, Endocrinology, 7th Ed., p. 1225 (W. B. Saunders Co., Philadelphia, 1974).

27. Preece, M., McIntosh, W., Tomlinson, S., Ford, J., Dunningan, M., and O'Riordan, J.: Vitamin D deficiency among Asian immigrants to Britain. Lancet, $i$ : 907 (1973).

28. Purvis, R., Mackay, G., Cockburn, F., McK Barrie, W., Wilkinson, E., Belton, N., and Forfar, J.: Enamel hypoplasia of the teech associated with neonatal tetany: A manifestation of maternal vitamin D deficiency. Lancet, ii: 811 (1973).

29. Pybus, J., Feldman, F., and Bowers, G.: Measurement of total calcium in serum by atomic absorption spectrophotometry, with use of a strontium internal reference. Clin. Chem., 16: 998 (1970).

30. Roberts, S., Cohen, M., and Forfar, J.: Antenatal factors associated with neonatal hypocalcemic convulsions. Lancet, ii: 809 (1973).

31. Roginsky, M., Abseamis, C., Moo, H., and Weiss, R.: 25-Hydroxycholecolciferal and calcium relationship in fullterm newborns and their mothers. In A. Norman, K. Schaefer, H. Grigoleit, D. Herrath, and E. Rita: Vitamin D and Problems Related to Uremic Bone Disease: Proceedings of the Second Workshop on Vitamin D, Weisbaden, West Germany, October 1974 (W. de Gruyter, New York, 1975). 
32. Rojanasathit, S., and Haddad, J.: Characterization of a new human calcitonin (HCT) radioimmunoassay (RIA). Clin. Chim. Acta (In press.)

33. Root, A., and Harrison, H.: Recent advances in calcium metabolism. I. Mechanisms of calcium homeostasis. J. Pediat., 88: 1 (1976).

34. Rosen, J., Roginsky, M., Nathenson, G., and Finberg, L.: 25-Hydroxyvitamin D: Plasma levels in mothers and their premature infants with neonatal hypocalcemia. Amer. J. Dis. Child., 127: 220 (1974).

35. Sorenson, O., Nellesen, C., and Hindberg, I.: The effect of diet and age on the response to calcitonin in rats. Acta Endocrinol., 65: 316 (1970).

36. Stamp, T., and Round, J.: Seasonal changes in human plasma levels of 25 hydroxy-vitamin D. Nature, 274: 563 (1974).

37. Suh, S., Tashjian, A., Jr., Matsuro, N., Parkinson, E., and Fraser, D.: Pathogenesis of hypocalcemia in primary hypomagnesemia: Normal endorgan responsiveness to parathyroid hormone, impaired parathyroid gland function. J. Clin. Invest., 52: 153 (1973).

38. Tsang, R.: Neonatal magnesium disturbances. Amer. J. Dis. Child., 124: 282 (1972).

39. Tsang, R., Chen, I.-W., Friedman, M., and Chen, I.: Neonatal parathyroid function: Role of gestational age and postnatal age. J. Pediat., 83: 728 (1973).

40. Tsang, R., Chen, I.-W., Friedman, M., Gigger, M., Steicher, J., Koffler, H., Fenton, L., Brown, D., Pramanik, A., Keenan, W., Stub, R., and Joyce, T.: Parathyroid function of infants of diabetic mothers. J. Pediat., 86: 399 (1975).

41. Tsang, R., Light, I., Sutherland, J., and Kleinman, L. I.: Possible pathogenetic factors in neonatal hypocalcemia of prematurity. J. Pediat., 82: 423
(1973).

42. Tsang, R., and Oh, W.: Serum magnesium levels in low birth weight infants. Amer. J. Dis. Child., I20: 44 (1970).

43. Tsang, R., and Oh, W.: Neonatal hypocalcemia in low birth weight infants Pediatrics, 45: 773 (1970).

44. Tsang, R., Strub, R., Brown, D., Streicher, J., Hartman, C., and Chen, I.W.: Hypomagnesia in infants of diabetic mothers: Perinatal studies. J. Pediat., 89: 115 (1976).

45. Watney, P., Chance, G., Scott, P., and Thomposn, J.: Maternal factors in neonatal hypocalcemia: A study in three ethnic groups. Brit. Med. J., 2: 432 (1971).

46. Wright, D., Ivey, J., and Tashjian, A.: Self-induced loss of calcitonin receptors in bone: a possible explanation for "escape." Clin. Res., 24: 461 A (1976).

47. We thank Dr. John Babcock of the Upjohn Company for his gift of reference 25-hydroxycholecalciferol, Mrs. S. Rei for her technical assistance, and Dr. Gerald Kessler for performing serum chemical analyses.

48. Dr. John G. Haddad is recipient of National Institutes of Health Career Development Award IK 8AM70, 343.

49. This research was supported by National Institute of Arthritis and Metabolic Disease Research Grants AM-05248 and AM-09976 and National Institutes of Health Grant AM 14570-06.

50. Requests for reprints should be addressed to: L. S. Hillman, M.D., St. Louis Children's Hospital, 500 S. Kingshighway, St. Louis, Mo., 63110 (USA).

51. Received for publication August 20, 1976.

52. Accepted for publication October 21,1976
Apgar score lipid

blood cholesterol

gel filtration lipoporteins ultracentrifugation umbilical cords

\title{
Separation and Characterization of Cord Serum Lipoproteins
}

\author{
M. D. MORRIS, ${ }^{(21)}$ J. A. LEE, AND M. R. BALDWIN \\ Departments of Pediatrics, Biochemistry, and Obstetrics-Gynecology and University of Arkansas for Medical \\ Sciences, Little Rock, Arkansas, USA
}

\section{Summary}

Blood was collected from the umbilical cords of infants with a 1-min Apgar score of 9 or 10. Total cord serum lipoproteins were isolated by ultracentrifugation, at a density of $1.220 \mathrm{~g} / \mathrm{ml}$. The isolated serum lipoproteins were then separated by gel filtration chromatography on $6 \%$ agarose. The overall recovery of the separated lipoprotein cholesterol was $90 \%$ or greater. In cord serum, four lipoprotein peaks were found, whereas three peaks were present in adult lipoproteins. The major lipoproteins of cord serum correspond to low density lipoprotein (LDL) and high density lipoprotein (HDL). Very low density lipoproteins (VLDL) were heterogeneous in cord serum. After gel filtration chromatography, the distribution of cord serum cholesterol is about $5 \%$ in peak $1,10 \%$ in peak $2,40 \%$ in peak 3 (LDL), and $45 \%$ in peak 4 (HDL). An additional difference between the lipoproteins isolated from cord serum and those from adult serum was the slower electrophoretic mobility of cord serum VLDL in agarose gel.

\section{Speculation}

The fetus, during the later stages of pregnancy, accumulates fat at an accelerating rate. Triglycerides, synthesized by the liver, are secreted as VLDL and transported to adipose tissue for degradation, probably by lipoprotein lipase.

The heterogeneity of cord blood VLDL and the presence of a significant amount of an intermediate lipoprotein fraction (designated peak 2) may be related to a partial metabolic block in the conversion of VLDL lipoproteins to smaller lipoproteins such as LDL.

Although there have been numerous reports dealing with the concentration of lipids and lipoproteins in cord blood, no comprehensive studies concerning the distribution, structure, and chemical composition of cord serum lipoproteins have been described $(1,3,6,7,8,11,13,17,18)$. Glueck et al. (7) have emphasized the importance of determination of cord blood cholesterol for the detection of heritable type II hyperlipoproteinemia. More recently, Kwiterovich et al. (11) have suggested that the concentration of low density lipoprotein cholesterol is of greater significance in the ascertainment of the affected child with type II hyperlipoproteinemia.

In order for cord blood screening techniques to be of diagnostic significance, a more complete understanding of the relation between cord serum lipids and lipoproteins will be required. To further study this relationship, a procedure has been used where 